\title{
Hubungan intensitas pemakaian gawai dengan neck pain pada usia 15-20 tahun
}

\author{
Yuni Tri Yustianti ${ }^{1}$ Pusparini $^{2}$
}

\begin{abstract}
ABSTRAK
\section{LATAR BELAKANG}

Dekade terakhir menunjukkan neck pain pada remaja semakin meningkat, bersamaan dengan meningkatnya penggunaan gawai (gadget). Seiring perkembangan zaman, gawai menjadi kebutuhan dan gaya hidup masyarakat luas. Pelajar menjadi pasar terbesar dalam penggunaan gawai sehubungan dengan kebutuhan belajar yang memerlukan akses Internet. Salah satu faktor penyebab neck pain pada pengguna gawai adalah intensitas penggunaan gawai yang mempengaruhi lamanya posisi fleksi pada otot leher. Tujuan penelitian ini adalah untuk mengetahui hubungan intensitas pemakaian gawai dengan neck pain pada usia 15-20 tahun.

\section{METODE}

Penelitian ini merupakan studi observasional dengan desain cross sectional yang mengikutsertakan 164 pelajar SMAN 28 Jakarta dan Fakultas Hukum Universitas Trisakti. Data dikumpulkan dengan cara pengisian kuesioner yang meliputi usia, jenis kelamin, intensitas pemakaian gawai dan keluhan neck pain. Penilaian neck pain menggunakan NRS (Numeric Rating Scale). Analisis data dilakukan dengan uji Chi-square dengan tingkat kemaknaan $\mathrm{p}<0.05$.
\end{abstract}

\section{HASIL}

Subjek perempuan berjumlah 121 orang (73.8\%). Paparan gawai dengan intensitas $>56$ jam/minggu dijumpai pada 109 subjek $(66.5 \%)$. Keluhan neck pain dijumpai pada 138 subjek (84.1\%). Uji Chi-square menunjukkan terdapat hubungan yang bermakna antara intensitas penggunaan gawai dengan neck pain pada usia 15-20 tahun dengan nilai $\mathrm{p}=0.004$.

\section{KESIMPULAN}

Terdapat hubungan yang bermakna antara intensitas penggunaan gawai dengan neck pain pada usia 15-20 tahun.

Kata kunci : intensitas penggunaan gawai, neck pain, pelajar, numeric rating scale

\author{
${ }^{1}$ Program Studi Kedokteran, \\ Fakultas Kedokteran, \\ Universitas Trisakti \\ ${ }^{2}$ Departemen Patologi Klinik, \\ Fakultas Kedokteran, \\ Universitas Trisakti

\section{Korespondensi:} \\ Pusparini \\ Departemen Patologi Klinik, \\ Fakultas Kedokteran, \\ Universitas Trisakti, \\ Jalan Kyai Tapa No. 260, Grogol, \\ Jakarta Barat 11440 \\ Email: pusparini@trisakti.ac.id
}

J Biomedika Kesehat 2019;2(2):71-76 DOI: 10.18051/JBiomedKes.2019. v2.71-76

pISSN: 2621-539X / eISSN: 2621-5470

Artikel akses terbuka (open access) ini didistribusikan di bawah lisensi Creative Commons Attribution 4.0 International (CC-BY 4.0) 


\section{ABSTRACT}

\section{Relationship between gadget usage and neck pain at age 15-20 years old}

\section{BACKGROUND}

Recent report shows that neck pain in youth has been increasing, occurring alongside the increasing amount of gadget usage. As the years advanced, gadget has been a primary need and lifestyle for the broad spectrum of people. The student has been the biggest market for the usage of gadget to support the needs for education access via the internet. One of the factor causing neck pain on gadget user is the intensity of gadget usage which affects the duration of flexed neck posture. The purpose of this study is to find the correlation between the intensity of gadget usage and neck pain among 15-20 years old.

\section{METHODS}

A cross-sectional observational study was conducted and a total of 164 students were included at SMAN 28 Jakarta and Faculty of Law Trisakti University. Data was collected by using questionnaire, covering age, gender, intensity of gadget usage and neck pain complaint. Assessment of neck pain was performed using NRS (Numeric Rating Scale). Data analysis was performed with Chi-square test with a level of significance $p<0.05$.

\section{RESULT}

Female subject were 121 respondents (73.8\%). Intensity gadget usage $>56$ hour/week were 109 subject $(66.5 \%)$. Neck pain complaint were 138 subject $(84.1 \%)$. Chi-square test showed that there was significant relationship between the intensity of gadget usage and neck pain among $15-20$ years old with $p=0.004$.

\section{CONCLUSION}

There was a significant relationship between the intensity of gadget usage and neck pain among 15-20 years old.

Keywords : intensity of gadget usage, neck pain, student, numeric rating scale

\section{PENDAHULUAN}

Neck pain didefinisikan sebagai nyeri yang dialami dari pangkal kepala (occiput) sampai bagian atas punggung dan meluas ke batas luar dan atas tulang belikat (skapula). ${ }^{(1)}$ Prevalensi neck pain pada remaja berkisar $15-30 \% \%^{(2,3)}$ Prevalensi neck pain meningkat seiring dengan bertambahnya usia. Keluhan neck pain mencapai $26 \%$ per minggu pada remaja dan terus meningkat. (2) Neck shoulder pain (NSP) juga umum terjadi pada remaja, setidaknya sekitar 1 dari 4 remaja melaporkan NSP setiap minggu. NSP pada remaja semakin meningkat, seiring dengan meningkatnya penggunaan komputer. ${ }^{(4,5)}$ Rata-rata penggunaan harian komputer pada usia 8-18 tahun di USA meningkat dari 0.5 jam di tahun 1999 menjadi 1 jam di tahun 2004 dan 1.5 jam di tahun 2009.(4)

Neck pain pada pengguna gawai dapat disebabkan oleh banyak faktor salah satunya intensitas penggunaan gawai yang memengaruhi lamanya posisi fleksi pada otot leher. ${ }^{(1,6,7)}$ Penyebab nyeri leher dapat dikaitkan dengan proses degeneratif atau patologi yang teridentifikasi dalam gambaran pencitraan diagnostik. Jaringan yang menjadi penyebab nyeri leher sering tidak diketahui sehingga klinisi harus menilai gangguan fungsi otot, jaringan, dan jaringan saraf yang terkait dengan jaringan patologis yang diidentifikasi saat pasien datang dengan nyeri leher. ${ }^{(8)}$ Penelitian yang dilakukan oleh Straker, et al menunjukkan pria dengan penggunaan komputer 14-21 jam per minggu memiliki posisi $3^{\circ}$ lebih fleksi pada leher dibandingkan dengan pria yang tidak menggunakan komputer, sedangkan pria yang menggunakan komputer lebih dari 21 jam per minggu memiliki posisi $4.5^{\circ}$ lebih fleksi pada leher. ${ }^{(5)}$

Saat ini, penggunaan media elektronik seperti komputer, ponsel, laptop, tablet dan gawai lainnya berkembang dengan pesat. ${ }^{(6,9-11)}$ Dengan harga yang terjangkau, gawai menarik minat masyarakat untuk menikmati segala keuntungan yang diberikan dalam penggunaannya. Keuntungan yang diberikan antara lain adalah kemudahan untuk berkomunikasi, menyelesaikan pekerjaan, dan sebagai penyedia aplikasi hiburan bagi penggunanya. ${ }^{(4)}$ Gawai sudah menjadi kebutuhan dan gaya hidup untuk masyarakat luas sehingga sangat umum digunakan pada seluruh kelompok usia. Saat ini, lebih dari 3 miliar penduduk dunia menggunakan ponsel akibat distribusi yang meningkat secara tiba-tiba. ${ }^{(9,10)}$ Pelajar menjadi pasar terbesar dalam penggunaan gawai sehubungan dengan kebutuhan belajar dan menyelesaikan tugas terutama yang memerlukan akses Internet. $^{(10,12)}$

Pada tahun 2013, pelanggan layanan seluler hampir mencapai seluruh penduduk dunia 
dan lebih dari setengahnya berada di wilayah AsiaPasifik (3.5 miliar dari total 6.8 miliar pelanggan layanan seluler). Tingkat pendistribusian ponsel mencapai $96 \%$ di seluruh dunia, 128\% di negara maju dan $89 \%$ di negara berkembang.(2) Tahun 2014, diperkirakan $42 \%$ populasi Amerika Serikat berusia 18 tahun atau lebih memiliki tablet. ${ }^{(6)}$

Penggunaan gawai dapat berakibat negatif terhadap kesehatan. ${ }^{(2)}$ Keluhan akibat penggunaan ponsel antara lain berupa neck pain (71.2\%), sakit kepala $(63.3 \%)$, kecemasan $(50.7 \%)$, penurunan konsentrasi $(47.4 \%)$, penegangan otot mata (36.8\%), insomnia (31.3\%), masalah pada ingatan (28.5\%), depresi (19.69\%), gatal dan atau eritema pada kulit periaurikular (16.91\%). ${ }^{(8)}$ Penggunaan gawai berhubungan dengan empat postur yaitu fleksi leher, sudut servikotorakal, trunk angle dan fleksi torakal. Pada keempat postur tersebut hanya fleksi leher yang berhubungan dengan penggunaan komputer dan menimbulkan pelvic tilt. ${ }^{(4)}$

Penelitian Vasavada, et al menunjukkan terdapat hubungan antara penggunaan gawai dengan neck pain dengan nilai $\mathrm{p}=0.001{ }^{(6)} \mathrm{Pada}$ penelitian Satali, et al juga menunjukkan terdapat hubungan natara penggunaan gawai dengan neck pain dengan odd Ratio 1.65 dan interval kepercayaan 1.24-2.19.(13) Sebaliknya Green, et al melaporkan tidak dapat menemukan korelasi antara postur tubuh yang disebabkan penggunaan gawai dengan nyeri yang ditimbulkan. ${ }^{(1)}$

\section{METODE}

Penelitian ini menggunakan desain cross sectional pada 164 subjek penelitian terdiri dari pelajar SMAN 28 Jakarta dan mahasiswa Fakultas Hukum Universitas Trisakti. Pengambilan sampel dilakukan dengan teknik simple random sampling, dengan kriteria inklusi berusia 15-20 tahun dan bersedia berpartisipasi dalam penelitian ini dengan menandatangani informed consent. Kriteria eksklusi adalah pelajar atau mahasiswa yang memiliki riwayat cidera leher, riwayat penyakit sendi atau abnormalitas struktur pada leher, dan memiliki gangguan penglihatan yang tidak dapat dikoreksi. Penelitian dilakukan setelah lulus kaji etik dari Fakultas Kedokteran Universitas Trisakti dengan no. 165/KER-FK/ $\mathrm{VII} / 2017$.

Pengambilan data karakteristik demografi berupa usia dan jenis kelamin serta intensitas pemakaian gawai dilakukan dengan menggunakan form isian biodata dan lama durasi penggunaan gawai. Intensitas pemakaian gawai dikategorikan menjadi 2 kategori berdasarkan total waktu penggunaan gawai selama satu minggu, yaitu $<56 \mathrm{jam} /$ minggu atau $\geq 56 \mathrm{jam} /$ minggu. Data neck pain diperoleh dengan menggunakan kuesioner Numeric Rating Scale (NRS). Kuesioner NRS berskala antara $0-10$, dan dibagi menjadi 4 kategori, yaitu kategori 0 tidak mewakili rasa sakit, 1-3 nyeri ringan, 4-6 nyeri sedang dan 7-10 nyeri berat. Analisis hubungan antara usia, jenis kelamin, dan intensitas penggunaan gawai dengan neck pain dilakukan dengan menggunakan program statistik dan uji Chi-square dengan tingkat kemaknaan sebesar 0.05.

\section{HASIL}

Tabel 1. Distribusi frekuensi dari usia, jenis kelamin, intensitas pemakaian gawai, dan neck pain

\begin{tabular}{|c|c|}
\hline \multicolumn{2}{|l|}{ Variabel } \\
\hline Jenis kelamin & \\
\hline Laki-laki & $43 \quad(26.2)$ \\
\hline Perempuan & 121 \\
\hline \multicolumn{2}{|l|}{ Usia } \\
\hline$<17$ tahun & $(51.2)$ \\
\hline$\geq 17$ tahun & $(48.8)$ \\
\hline \multicolumn{2}{|l|}{ Intensitas pemakaian gawai } \\
\hline Paparan sedang $(<56 \mathrm{jam} / \mathrm{minggu})$ & $55 \quad(33.5)$ \\
\hline Paparan tinggi $(\geq 56 \mathrm{jam} / \mathrm{minggu})$ & $109(66.5)$ \\
\hline \multicolumn{2}{|l|}{ Neck pain } \\
\hline Ya & $138(84.1)$ \\
\hline Tidak & $26 \quad(15.9)$ \\
\hline
\end{tabular}

Dari Tabel 1 dapat terlihat bahwa jenis kelamin terbanyak dari subjek penelitian ini adalah perempuan berjumlah 121 orang $(73.8 \%)$. Rentang usia responden adalah 15-20 tahun. Usia terbanyak adalah kategori $<17$ tahun sejumlah 84 orang (51.2\%). Dari 164 responden, sebanyak 109 orang $(66.5 \%)$ memakai gawai selama $\geq 56$ jam/minggu. Sebanyak 138 responden (84.1\%) mengalami neck pain.

Pada Tabel 2 terlihat bahwa dari 164 responden yang mengikuti penelitian, sebanyak 81 orang $(96.4 \%)$ termasuk dalam kategori usia $<17$ tahun mengeluh mengalami neck pain setelah menggunakan gawai. Perempuan lebih lebih banyak yang mengalami neck pain yaitu sejumlah 106 orang $(87.6 \%)$ dibandingkan dengan laki- 
laki. Pengguna gawai dengan intensitas $\geq 56$ jam dalam satu minggu lebih banyak (89.9\%) mengalami neck pain daripada pengguna gawai $<56$ jam seminggu (72.7\%) dan hasil uji Chisquare menunjukkan perbedaan bermakna $(\mathrm{p}=0.004)$. Hasil uji Chi-square menunjukkan terdapat hubungan bermakna antara usia, jenis kelamin dengan kejadian neck pain dengan nilai $\mathrm{p}$ berturut-turut adalah $\mathrm{p}=0.000$ dan $\mathrm{p}=0.042$.

\section{PEMBAHASAN}

Hasil penelitian ini menunjukkan proporsi terbanyak usia responden yang mengeluh mengalami neck pain adalah kategori usia $<17$ tahun (96.4\%). Hal ini sesuai dengan penelitian Cox, et al yang melaporkan keluhan neck pain terbanyak pada remaja usia 13-15 tahun. ${ }^{(14)}$ Penelitian Fares, et al juga menyatakan bahwa sebanyak $87 \%$ subjek penelitiannya yaitu anak dan remaja mengalami neck pain. Seluruh subjek pada penelitian Fares, et al, waktu menggunakan gawai atau belajar berada pada posisi fleksi kepala yang salah (flawed flexion). ${ }^{(15)}$ Ariens, et al melaporkan adanya hubungan antara fleksi pada leher dengan neck pain. Terjadi peningkatan risiko terjadinya neck pain pada individu yang pada waktu belajar dengan posisi fleksi sedikitnya $20^{\circ}$ dengan waktu lebih dari $70 \%$ dari seluruh waktu belajarnya. ${ }^{(16)}$ Terdapat sindrom "Text neck" yaitu suatu sindrom yang terjadi pada abad ke 21 yang merupakan suatu terminologi mulai dari terjadinya degenerasi pada vertebra servikal sebagai akibat stres yang berulang dari posisi fleksi kepala pada waktu melihat gawai dan mengetik pada gawai untuk waktu yang lama. Text neck lebih sering terjadi terutama pada anak berusia belasa tahun sampai remaja terutama karena penggunaan smartphones.
(17) Pada penelitian ini, responden yang berusia antara 15-16 tahun adalah siswa SMAN 28 Jakarta yang telah menerapkan sistem CBT (Computer Based Test). Dalam kesehariannya, siswa menggunakan laptop untuk mengerjakan tugas dan menjalani ujian maupun remedial. Pada penelitian Palm, et al pelajar SMA di Swedia berusia 16-18 tahun, hampir seluruh siswa SMA di Swedia saat ini memiliki akses komputer di sekolah maupun di rumah sehingga pada usia tersebut pemakaian komputer dengan durasi yang lama sudah menjadi bagian dari kesehariannya, termasuk aktivitas mengerjakan tugas sekolah, bermain game dan akses Internet menggunakan komputer. $^{(18)}$

Pada penelitian ini, perempuan yang mengalami neck pain sebanyak 106 orang $(87.6 \%)$ dan laki-laki sebanyak 32 orang (74.4\%) (Tabel 2). Hasil uji Chi-square menunjukkan terdapat hubungan yang bermakna antara jenis kelamin dengan neck pain dengan $\mathrm{p}=0.042$. Hasil ini sejalan dengan penelitian yang dilakukan oleh Palm, et al bahwa jenis kelamin yang lebih banyak mengeluhkan neck pain adalah perempuan. ${ }^{(18)}$ Hal tersebut kemungkinan disebabkan oleh faktor fisiologi, sebagai contoh, umumnya perempuan memiliki tubuh yang lebih kecil dan bahu yang lebih sempit dibandingkan dengan laki-laki. Keyboard normal seringkali terlalu lebar untuk perempuan, sehingga dalam penggunaannya posisi bahu menjadi rotasi keluar atau posisi abduksi saat menggunakan mouse. ${ }^{(18)}$ Selain itu, berdasarkan metode pengukuran baik subjektif maupun objektif menunjukkan tingkat sensitivitas terhadap nyeri lebih tinggi pada perempuan dibandingkan dengan laki-laki. (18) Penelitian lainnya menunjukkan bahwa gejala

Tabel 2. Hubungan usia, jenis kelamin dan intensitas pemakaian gawai dengan neck pain

\begin{tabular}{|c|c|c|c|c|}
\hline \multirow[b]{2}{*}{ Variabel } & \multicolumn{2}{|c|}{ Neck pain } & \multirow[b]{2}{*}{ Total } & \multirow[b]{2}{*}{$\mathbf{p}$} \\
\hline & $\begin{array}{c}\text { Ya } \\
\mathbf{n}(\%) \\
\end{array}$ & $\begin{array}{l}\text { Tidak } \\
\text { n(\%) }\end{array}$ & & \\
\hline \multicolumn{5}{|l|}{ Usia } \\
\hline$<17$ tahun & $81(96.4)$ & $3(3.6)$ & $84(100.0)$ & $0.000^{*}$ \\
\hline$\geq 17$ tahun & $57(71.3)$ & $23(28.8)$ & $80(100.0)$ & \\
\hline \multicolumn{5}{|l|}{ Jenis kelamin } \\
\hline Laki-laki & $32(74.4)$ & $11(25.6)$ & $61(100.0)$ & $0.042 *$ \\
\hline Perempuan & $106(87.6)$ & $15(12.4)$ & $103(100.0)$ & \\
\hline \multicolumn{5}{|l|}{ Intensitas pemakaian gawai } \\
\hline Paparan sedang $(<56$ jam/minggu $)$ & $40(72.7)$ & $15(27.3)$ & $55(100.0)$ & $0.004 *$ \\
\hline Paparan tinggi ( $\geq 56$ jam/minggu $)$ & $98(89.9)$ & $11(10.1)$ & $109(100.0)$ & \\
\hline
\end{tabular}

Keterangan: $\mathrm{n}=$ frekuensi; $\%=$ presentase

$* \mathrm{p}<0.05$ berbeda bermakna uji Chi Square 
muskuloskeletal umum terjadi diantara remaja Swedia terutama perempuan. ${ }^{(18)}$ Al-Huthail, et al membuktikan hal yang sama dalam penelitiannya bahwa lebih banyak perempuan yang mengeluhkan neck pain dibandingkan dengan laki-laki, dan temuan ini konsisten dengan acuan referensi penelitian sebelumnya di Saudi Arabia. ${ }^{(19)}$ Akan tetapi, berdasarkan hasil review penelitian epidemiologi mengenai gangguan otot rangka dengan faktor di tempat kerja, National Institute of Safety and Health (NIOSH) melaporkan bahwa terdapat perbedaan hasil pada variabel penelitian hubungan jenis kelamin dengan keluhan otot rangka. Sebagian penelitian mendapatkan hasil bahwa keluhan otot rangka lebih tinggi pada perempuan, sedangkan penelitian lainnya melaporkan tidak ada perbedaan antara perempuan dan laki-laki pada keluhan otot rangka. ${ }^{(15)}$

Hasil analisis antara lamanya penggunaan gawai dan keluhan necak pain diperoleh hasil 98 orang $(89.9 \%)$ yang menggunakan gadget $\geq 56$ jam/minggu mengeluhkan neck pain. Sementara, responden yang menggunakan gawai dengan intensitas $<56 \mathrm{jam} /$ minggu dan mengeluhkan neck pain sejumlah 40 orang (72.7\%) (Tabel 2). Hasil uji Chi-square mendapatkan nilai $\mathrm{p}=0.004$ yang menunjukkan terdapat hubungan yang bermakna antara intensitas pemakaian gawai dengan neck pain. Hal ini sejalan dengan penelitian yang dilakukan oleh Palm, et al dengan hasil rasio prevalensi meningkat signifikan pada kategori pajanan tinggi terhadap komputer $(\geq 56 \mathrm{jam} /$ minggu) untuk keluhan neck pain. ${ }^{(18)}$ Penelitian ini menguatkan temuan sebelumnya bahwa gejala neck pain berhubungan dengan penggunaan gawai pada remaja. ${ }^{(18)}$ Hubungan antara lama penggunaan gawai dengan keluhan neck pain kemungkinan disebabkan pada waktu menggunakan gawai, posisi kepala dalam kondisi fleksi. Keluhan neck pain akan meningkat bila seseorang dalam posisi fleksi minimum $20^{\circ}$ selama $70 \%$ waktu yang digunakan. ${ }^{(17)}$ Diperkirakan $75 \%$ dari seluruh populasi dunia menghabiskan waktunya berjamjam dengan gawainya dengan posisi kepala fleksi. (15) Pada penelitian ini subjek yang menghabiskan waktu minimal 8 jam per hari dengan kepala dalam posisi fleksi untuk membaca dan/atau mengetik pada gawainya. Bila diakumulasikan dalam setahun maka minimal dihabiskan waktu sekitar 2.688 jam per tahun sehingga menyebabkan stress yang berlebih pada area sekitar servikal. Dengan posisi fleksi tersebut beban pada tulang vertebra servikal sangat meningkat. Berat kepala sekitar 4.54 sampai $5.44 \mathrm{~kg}$ pada posisi netral. Bila kepala dikedepankan/fleksi, maka tekanan pada leher akan meningkat menjadi $12.25 \mathrm{~kg}$ pada sudut $15^{\circ}, 18.14 \mathrm{~kg}$ pada sudut $30^{\circ}, 22.23 \mathrm{~kg}$ pada sudut $45^{\circ}$ dan $27.22 \mathrm{~kg}$ pada sudut $60^{\circ} .{ }^{(21)}$ Menurut Hansraj, anak-anak sekolah menengah atas mungkin menghabiskan waktu kira-kira 5000 jam tambahan pada postur tubuh yang salah. ${ }^{(21)}$ Posisi fleksi kepala yang sering menyebabkan perubahan pada tulang servikal, kurvatura, ligamen, tendon dan otot di daerah leher, yang pada akhirnya menyebabkan perubahan postur dan menimbulkan nyeri di leher dan area lain yang berhubungan dengan kondisi ini. ${ }^{(17)}$ Efek fleksi pada leher yang pada awalnya menimbulkan nyeri lama kelamaan dapat menimbulkan berbagai komplikasi. Seiring dengan berjalannya waktu posisi fleksi kepala dalam jangka waktu lama akan menimbulkan efek yang merugikan pada mata, paru-paru, dan jantung. ${ }^{(17)}$

Pada penelitian ini terdapat berbagai keterbatasan yaitu metode yang digunakan adalah metode cross sectional sehingga tidak dapat mengetahui hubungan sebab akibat antara penggunaan gawai dan neck pain. Selain itu, pada penelitian ini juga tidak diperinci jenis gawai yang digunakan serta posisi fleksi subjek pada waktu penggunaan gawai juga tidak diukur. Implikasi penelitian ini adalah pentingnya seseorang yang menggunakan gawai untuk menyadari pentingnya pengelolaan waktu penggunaan gawai sehingga tidak mengakibatkan keluhan pada leher baik antara lain berupa pembatasan waktu penggunaan gawai. Selain itu, perlu dilakukan penelitian lanjutan mengenai lama waktu yang diperkenankan untuk menggunakan gawai dan tidak menimbulkan keluhan neck pain, juga posisi yang benar untuk menggunakan gawai.

\section{KESIMPULAN}

Terdapatnya hubungan bermakna antara intensitas pemakaian gawai dengan neck pain pada usia 15-20 tahun.

\section{UCAPAN TERIMA KASIH}

Peneliti mengucapkan terima kasih kepada pihak SMAN 28 Jakarta dan FH Usakti yang telah 
memberikan izin dilakukannya pengambilan data untuk penelitian ini.

\section{KONFLIK KEPENTINGAN}

Penulis menyatakan tidak ada konflik kepentingan.

\section{DAFTAR REFERENSI}

1. Green BN. A literature review of neck pain associated with computer use: public health implications. J Can Chiropr Assoc 2008;52:161-7.

2. Korpinen L, Pääkkönen R, Gobba F. Self-reported neck symptoms and use of personal computers, laptops and cell phones among Finns aged 18-65. Ergonomics 2013;56:1134-46. Doi: https:// doi.org/10.1080/00140139.2013.802018

3. Richards KV, Beales DJ, Smith AJ, et al. Neck posture clustersand their association with biopsychosocial factors and neck pain in Australian adolescents. Physical Ther 2016;96:1576-87.

4. Straker LM, Smith AJ, Bear N, et al. Neck/ shoulder pain, habitual spinal posture and computer use in adolescents: the importance of gender. Ergonomics 2011;54:539-46.

5. Shan Z, Deng G, Li J, et al. Correlational analysis of neck/shoulder pain and low back pain with the use of digital products, physical activity andpsychological status among adolescents in Shanghai. Plos One 2013;8:1-9.

6. Vasavada AN, Nevins DD, Monda SM, et al. Gravitational demand on the neck musculature during tablet computer use. Ergonomics 2015;58:990-1004.

7. Xie Y, Szeto GPY, Dai J, et a l. A comparison of muscle activity in usingtouchscreen smartphone among young people with and without chronic neck-shoulder pain. Ergonomics 2015:1-12: DOI 10.1007/s00586-015-4143-3.

8. Childs JD, Cleland JA, Elliott JM, et al. Neck Pain: Clinical Practice Guidelines Linked to the International Classification ofFunctioning, Disability and Health From the Orthopaedic Section of the American Physical Therapy Association. J Orthop Sports Phys Ther 2008;38:22-34.

9. Al-Zarea BK, Patil SR. Mobile Phone Head and Neck Pain Syndrome: Proposal of a New Entity. OHDM 2015;14:313-7.

10. Xie YF, Szeto G, Dai J. Prevalence and risk factors associated with musculoskeletal complaints among users of mobile handheld devices: A systematic review. Applied Ergonomics 2017;59:132-42.

11. Korpinen L, Pääkkönen R. Physical symptoms in young and their use of different computers and mobile phones. Int JOSE 2011;17:361-71.

12. Akinbinu TR, Mashalla YJ. Impact of computer technology on health: computer vision syndrome (CVS). Medical Prac and Rev 2014;5:20-30. DOI 10.5897/MPR.2014.0121.

13. Stalin P, Abraham SB, Kanimozhy K, et al. Mobile Phone Usage and its Health Effects Among Adults in a Semi-Urban Area of Southern India. J Clin Diagnos Res 2016;10:14-6. doi10.7860/ JCDR/2016/16576.7074.

14. Cox J, Davidian C, Mior S. Neck pain in children: a retrospective case series. J Can Chiropr Assoc 2016;60:212-9.
15. Fares J, Fares MY, Fares Y. Muskuloskeletal neck pain in children and adolescents: Risk factors and complications. Surg Neurolol Int 2017;8:72. doi:10.4103/sni.sni_445_16.

16. Ariens GAM, Borghouts JAJ, Koes BW. Neck Pain. In : Crombie IK, Croft PR, Linton SJ, LeResche L, Korff M, editors. Epidemiology of pain. Seattle:IASP Press;1999.pp.235-6.

17. Chronic Conditions Team. Text Neck: is smarphone use causing your neck pain? Healthessentials. 2015. https://health.elevelandclinic.org/201/03/ text-neck-is-smartphone-use-causing-your-neckpain/.

18. Palm P, Risberg EH, Mortimer $M$, et al. Computer use, neck and upper-extremity symptoms, eyestrain and headache among female and male upper secondery school students. SJWH Suppl 2007:33-41.

19. Al-Huthail I, Al-Otaibi S, Al-Zahrani AS. Managerial work, exercise, smoking, and gender as determinants of neck and shoulder pain in office workers. Saudi J Sports Med 2017; 17:75-8.

20. Tana L, Delima, Tuminah S. Hubungan lama kerja dan posisi kerja dengan keluhan otot rangka leher dan ekstremitas atas pada pekerja garmen perempuan di Jakarta Utara. Bul Pen Kes 2009;37:12-22.

21. Hansraj KK. Assessment of stresses in the cervical spine caused by posture and position of the head. Surg Technol Int 2014;25:277-9. 